\title{
PENGEMBANGAN WIRAUSAHA \\ DALAM MENINGKATKAN SUMBER DAYA ISTERI NELAYAN MASYARAKAT PESISIR KABUPATEN BATANG
}

\author{
Devy Kusumaningrum ${ }^{1 *}$, Karjono ${ }^{2}$ \\ ${ }^{1}$ Program Studi Nautika, Politeknik Bumi Akpelni \\ ${ }^{2}$ Program Studi KPN, Politeknik Bumi Akpelni \\ Jl. Pawiyatan Luhur II/17, Bendan Dhuwur, Semarang. \\ "Email: devy@akpelni.ac.id
}

\begin{abstract}
Abstrak
Desa Senturi, Karangasem Utara, Kabupaten Batang, merupakan masyarakat nelayan karena kehidupan sehari-harinya sering melaut dan bekerja sebagai nelayan, namun yang menjadi kendala saat ini yaitu masih kurangnya sumber daya manusia terutama SDM isteri Nelayan karena hanya menunggu dari hasil tangkap suami. Dalam kajian ini menggunakan pendekatan metode kualitatif, untuk memahami fenomena tentang apa yang dialami dan subjek penelitian adalah terkait dengan perilaku, persepsi, motivasi, dan tindakan lain-lain untuk memahami fenomena kebiasaan aktifitas istri nelayan. Informan ditentukan dengan melibatkan kelompok nelayan yang terdiri dari 64 isteri nelayan. Pengumpulan data dilakukan dengan wawancara mendalam, dokumentasi. Pengujian keabsahan data menggunakan teknik triangulasi. Hasil penelitian menunjukkan bahwa peran isteri dalam ruang lingkup rumah tangga disamping mengurus rumah tangga adalah sebagai penjual ikan, menentukan harga ikan, dan melaksanakan pelatihan wirausaha mandiri hingga mengikuti pendampingan bisa memasarkan produk. Namun disisi lain, masih kurangnya pemahaman masyarakat terutama terhadap teknologi digitial pemasaran produk merupakan hal yang perlu diperhatikan leih lanjut.
\end{abstract}

Kata kunci : isteri nelayan, pemasaran, dan wirausaha

\section{PENDAHULUAN}

Permasalahan perekonomian pesisir pantai merupakan masalah yang sangat kompleks. Sebagian besar masyaratakat pesisir akan sangat bergantung pada kehidupan Laut, pada umumnya mereka hanya terfokus pada hasil tangkapan dari kepala rumah tangga. Meningkatnya pertumbuhan penduduk dan intensifnya interaksi antara manusia dengan lingkungan tanpa adanya kesadaran pentingnya meningkatkan ketrampilan istri para nelayan, Penghasilan nelayan yang tidak menentu tergantung pada kondisi cuaca. Pada saat tertentu nelayan tidak mendapatkan hasil tangkapan sesuai dengan biaya operasional. Cuaca yang tidak menentu dan tidak selamanya sesuai yang diharapkan membuat nelayan memiliki nasib yang tidak menentu pula.

Berbagai faktor menjadi penyebab mengapa hal tersebut dapat terjadi. Yang pertama ialah rendahnya tingkat pendidikan yang pada akhirnya membuat masyarakat di kawasan ini tidak bisa mengelola sumber daya alam secara maksimal dan mengelola keuangan dengan baik. Pola hidup yang tidak semestinya secara finansial, ketika nelayan mengalami over-produksi, pola konsumerisme nelayan menjadi penyebab mereka mengalami keadaan finansial yang buruk. Umumnya para nelayan akan membelanjakan uang hasil panen mereka untuk kebutuhan sekunder sehingga ketika mereka mengalami keterpurukan mereka menjual kembali barang-barang tersebut dan pada akhirnya mereka harus merugi. Kemudian yang kedua ialah karena terdapat struktur patron-klien. Nelayan tradisional yang notabene memiliki modal yang kecil terpaksa harus meminjam dan mendapatkan modal dari para tengkulak. Dengan demikian kondisi kekurangan yang pada akhirnya menyebabkan kemiskinan secara struktural ini terus menerus menimpa masyarakat nelayan. Berbagai upaya sudah dilakukan oleh masyarakat nelayan untuk meningkatkan kesejateraannya. Namun kadang-kadang mereka terjebak pada posisi yang lebih buruk. Bahkan sering dengan 
rasa terpaksa, hasil tangkapan yang diperoleh dihargai dengan harga yang relatif murah oleh para pemilik modal atau tengkulak. Minimnya sumber daya manusia dan kondisi patron-klien ini menyebabkan belenggu yang susah dilepaskan oleh para masyarakat nelayan di kawasan ini. Lebih jauh lagi selama musim dilarang untuk melaut semisal ketika sering terjadi hujan dan juga musim Tera'an, musim tera'an disini adalah musim dimana para ikan tidak keluar ke permukaan laut karena ada sinar bulan yang menyinari laut, sehingga para nelayan yang biasanya memanfaatkan lampu sorot untuk dijadikan pancingan agar ikan keluar ke permukaan tidak berfungsi dengan baik, akibatnya para nelayan beserta keluarganya banyak menganggur. Dengan demikian income mereka terganggu dalam manajemen keuangan. Ketika fenomena seperti ini disikapi dengan perspektif sistem yang lazim digunakan dalam Ilmu Kesejahteraan Sosial, maka terjadi hal yang menggangu keluarga sebagai institusi sosial. Ibu atau istri yang seharusnya melakukan pekerjaan rumah memiliki peran ganda sebagai seorang yang juga harus memiliki kemampuan untuk mencukupi kebutuhan sehari-hari. Isu kesejahteraan dan upayaupaya mencapai kesejahteraan terus dilakukan oleh pemerintah, hal tersebut masih belum bisa dirasakan manfaatnya, khususnya pada masyarakat nelayan. Pengalaman selama ini telah menunjukkan bahwa tidak mudah mengatasi kemiskinan struktural yang membelenggu nelayan tradisional di berbagai segi kehidupan. Bahkan lewat hasil-hasil studi tentang pengembangan wirausaha dalam meningkatkan sumber daya isteri nelayan masyarakat pesisir Kabupaten Batang sangat mereka harapkan, peran Perguruan Tinggi melalui program pengabdian masayarakat yang bersifat kontinyu dalam pendampingan melaui pelatiahan ketrampilan sampai dengan pemasaran menciptakan peluang baru bagi mereka untuk memperbaiki dari sektor ekonomi dan kesejateraan. Adanya ketergantungan pada hasil Laut yang selama ini berperan besar dalam memerosotkan kemampuan si miskin untuk bargaining dalam dunia hubungan sosial yang sudah timpang antara tengkulak atau pemodal dan nelayan yang tidak bisa mendapatkan harga yang layak atas barang yang mereka jual (Kusnadi, 2002:26-27). Keberadaan serba kekurangan itulah yang pada akhirnya membuat para istri dalam keluarga nelayan di daerah kabupaten Batang banyak yang melakukan campur tangan ikut bekerja membantu suaminya. Terlihat ketika menjelang pagi hari para istri nelayan berbondong-bondong pergi ke pelelangan untuk membeli ikan, ada juga yang duduk-duduk di pelabuhan kapal nelayan menunggu para suaminya yang melaut, dan ada pula istri yang mengemasi ikan untuk dijajakan ke pasar. Oleh karena itu, peneliti ingin melakukan penelitian dilingkungan isteri nelayan jenis pengembangan wirausaha selain hasil tangkapan laut dalam meningkatkan sumber daya isteri nelayan masyarakat pesisir kabupaten batang

\section{TINJAUAN PUSTAKA \\ Pengertian wirausaha}

Peranan wirausaha dalam suatu bangsa sangatlah penting. Wirausaha diharapkan dapat membantu mengatasi permasalahan pengangguran, karena dapat menciptakan peluang kerja bagi orang lain. Pengertian wirausaha yang dikenal secara umum adalah membuka usaha yang mandiri dalam bidang tertentu. Agar tidak terjadi suatu kekeliruan dalam pengertian mengenai wirausaha maka perlu dikaji untuk memperoleh suatu kejelasan mengenai wirausaha. Berikut beberapa pengertian mengenai wirausaha menurut para ahli :

1. Joseph Schumpeter dalam Buchori Alma (2011: 24) Wirausaha adalah orang yang mendobrak sistem ekonomi yang ada dengan memperkenalkan barang dan jasa yang baru dengan menciptakan bentuk organisasi baru atau mengolah bahan baku baru". Dari definisi di atas ditekankan bahwa seorang wirausaha adalah orang yang 
melihat peluang kemudian menciptakan sebuah organisasi baru dan memanfaatkan peluang tersebut.

2. Menurut Kasmir (2011:19)

Wirausahawan adalah orang yang berjiwa berani mengambil resiko untuk membuka usaha dalam berbagai kesempatan. Berjiwa berani mengambil resiko artinya bermental mandiri dan berani memulai usaha, tanpa diliputi rasa takut atau cemas sekalipun dalam kondisi tidak pasti.

3. Menurut Suryana (2003:1)

Wirausaha adalah kemampuan kreatif dan inovatif yang dijadikan dasar, kiat dan sumber daya untuk mencari peluang menuju sukses. Inti dari kewirausahaan adalah kemampuan untuk menciptakan sesuatu yang baru dan berbeda (create new and different) melalui berpikir kreatif dan bertindak inovatif untuk menciptakan peluang.

Seorang inovator dan wirausaha yang terkenal dan sukses membangun sebuah bisnis besar, umumnya mereka bukan penanggung resiko, tetapi mereka mencoba mendefinisikan resiko yang harus mereka hadapi dan mereka meminimalkan resiko tersebut. Dari definisi di atas, dapat disimpulkan bahwa wirausahawan adalah seseorang yang memulai sesuatu bisnis baru, bisa memanfaatkan peluang dengan menggunakan waktu yang disertai modal dan resiko serta menerima balas jasa. Hal tersebut menunjukan bahwa wirausaha tidak hanya mengandalkan modal saja.

\section{Tahap-tahap Wirausaha}

Menurut (Kasmir, 2011:96) secara umum tahap-tahap melakukan wirausaha :

1. Tahap memulai Tahap dimana seseorang yang berniat untuk melakukan usaha mempersiapkan segala sesuatu yang diperlukan, diawali dengan melihat peluang usaha baru yang mungkin apakah membuka usaha baru, melakukan akuisisi, atau melakukan "franchising". Tahap ini juga memilih jenis usaha yang akan dilakukan apakah dibidang pertanian, industri atau jasa.

2. Tahap melaksanakan usaha Dalam tahap ini seorang wirausahawan mengelola berbagai aspek yang terkait dengan usahanya, mencakup aspekaspek:pembiayaan, SDM, kepemilikan,organisasi, kepemimpinan yang meliputi bagaimana mengambil resiko dan mengambil keputusan, pemasaran, dan melakukan evaluasi.

3. Tahap mempertahankan usaha Tahap dimana wirausahawan berdasarkan hasil yang telah dicapai melakukan analisis perkembangan yang dicapai untuk ditindak lanjuti sesuai dengan kondisi yang dihadapi

4. Tahap mengembangkan usaha Tahap dimana jika hasil yang diperoleh tergolong positif atau mengalami perkembangan atau dapat bertahan maka perluasan usaha menjadi salah satu pilihan yang mungkin diambil.

Berdasarkan definisi di atas, untuk menjadi seorang wirausaha yang sukses maka harus bekerja keras, mempunyai semangat juang yang tinggi, dan yakin terhadap kemampuan karena untuk menjadi seorang wirausaha yang sukses tidak mudah. Setiap kegiatan wirausaha pasti melewati masa kritis, dengan adanya kerja keras, semangat juang, dan keyakinan yang kuat maka segala kendala bisa teratasi.

\section{Pengembangan Manusia}

Sumber Daya

Pengembangan merupakan sebuah keharusan yang harus diaplikasikan dalam kehidupan, Kata konsep artinya ide, rancangan atau pengertian yang diabstrakkan dari peristiwa konkrit (Kamus Besar Bahasa Indonesia , 2002 :589) sedangkan pengembangan artinya proses, cara perbuatan mengembangkan (Kamus Besar Bahasa Indonesia, 2002 : 538). Dengan demikian konsep

pengembangan adalah rancangan mengembangkan sesuatu yang sudah ada dalam rangka meningkatkan kualitaslebih maju. 


\section{Upaya-upaya Pengembangan Sumber Daya Manusia}

1. Pendidikan

Secara sederhana pendidikan bisa di artikan sebagai usaha untuk mengarahkan peserta didik dari yang tidak tahu. Sehingga dengan memiliki pengetahuan maka seseorang akan menjadi lebih terarah dalam menentukan maupun mengambil keputusan.

2. Peningkatan pengetahuan dan wawasan lingkungan Pengetahuan dan wawasan lingkungan penting di terapkan pada masyarakat agar dapat meningkatkan pengembangan sumber daya manusia untuk membarikan konsep dan pandangan yang sama dan benar kepada masyarakat tentang linkungan dan perannya terhadap kehidupan masyarakat secara keseluruhan. Pengetahuan dan wawasan yang diberikan pada masyarakat harus dilihat dari lingkungan dan jenis pekerjaannya agar lebih spesifik dan lebih menekankan pada pengetahuan dan wawasan yeng berkaitan lansung dengan sumber daya yang ada. Cara yang tepat untuk meningkatkan pengetahuan dan wawasan lingkungan pada masyarakat perlu dilakukan penyuluhan dan pelatihan di lingkungan masyarakat agar masyarakat dapat mengetahui perannya terhadap lingkungan. Peningkatkan pengetahuan dan wawasan juga perlu melibatkan Perguruan tinggi dan aparatur desa dan kecamatan.

3. Pengembangan keterampilan masyarakat Peningkatan keterampilan masyarakat untuk dapat meningkatkan sumber daya manusia dari pengelolaan lingkungan harus ada campur tangan dari pemerintah untuk mendorong peran serta dari seluruh masyarakat secara aktif. Keterampilan sangatlah penting dimiliki oleh setiap masyarakat karena pengembangan keterampilan dapat membantu masyarakat dalam meningkatkan kualitas kerja yang lebih terampil dan cekatan dalam melakukan pekerjan. Keterampilan tersebut terutama berkaitan dengan cara-cara pemanfaatan sumber daya dari istri yang ada di masyarakat pesisir bagaimana masyarakat memanfaatkan potensi sumber daya parikanan dengan keterampilan yang dimiliki oleh masyarakat.

\section{Sumber Daya Manusia}

Soebagio Atmodiwirio (2002) mengungkapkan beberapa definisi sumber daya manusia dari berbagai sumber:

a. Sumber daya manusia adalah tenaga kerja yang tersedia, termasuk jumlah dan pengetahuan mereka, keterampilannya, dan kemampuannya.

b. Sumber daya manusia adalah sejumlah peran dan keterampilan yang dibutuhkan oleh manusia.

c. Sumber daya manusia adalah kekuatan daya pikir dan berkarya manusia yang masih tersimpan dalam dirinya yang perlu dibina dan digali, serta dikembangkan untuk dimanfatkan sebaik-baiknya bagi kesejahteraan kehidupan manusia.

\section{Konsep Masyarakat Nelayan}

Secara geografis, masyarakat nelayan adalah masyarakat yang hidup tumbuh dan berkembang di kawasan pesisir, yakni suatu kawasan transisi antara wilayah darat dan laut. Sebagai suatu sistem, masyarakat nelayan terdiri atas kategori-kategori sosial yang membentuk kesatuan sosial. Mereka juga memiliki sistem nilai dan simbol kebudayaan sebagai referensi prilaku mereka sehari-hari. Faktor ini merupakan salah satu pembeda masyarakat nelayan dengan masyarakat lainnya sebab sebagian besar masyarakat pesisir menggantungkan hidupnya dari mengelola potensi sumberdaya perikanan dan mereka juga berperan sebagai komponen utama kontruksi masyarakat maritim Indonesia Disisi lain, pemerintah telah menetapkan konsep masyarakat nelayan sebagaimana terdapat dalam UU tentang perikanan No. 31 tahun 2004 yang berbunyi : 
"Nelayan adalah orang yang mata pencahariannya adalah melakukan penangkapan ikan, selanjutnya dalam realita sosial nelayan terbagi dalam dua hal, yakni nelayan besar atau pemilik dan nelayan kecil atau nelayan buruh. Menurut UU Tentang Perikanan No.31 Tahun 2004, nelayan kecil adalah orang yang mata pencahariannya adalah melakukan penangkapan ikan."

Jauh lebih spesifik, pengertian nelayan juga disampaikan oleh Ditjen Perikanan yang menyatakan bahwa:

"Sebagai orang yang secara aktif melakukan pekerjaan dalam operasi penangkapan ikan, binatang air lainnya atau tanaman air. Adapun orang yang hanya melakukan pekerjaan seperti membuat jaring atau mengangkut alat-alat perlengkapan ke dalam perahu atau kapal tidak dikategorikan sebagai nelayan. Sementara itu, ahli mesin dan juru masak yang bekerja di atas perahu atau kapal di sebut sebagai nelayan meskipun mereka tidak secara langsung melakukan penangkapan ikan". artian tidak ada penghasilan atau pemasukan bagi keluarga nelayan pada musim tersebut. Kebanyakan dari mereka menghabiskan waktunya dengan duduk- duduk bersantai dengan sanak saudaranya. Sering kali aktifitas tersebut menjadi rutinitas setiap hari selama kondisi cuaca masih belum memastikan untuk berlayar. Oleh karena itu, untuk memenuhi kebutuhan sehari-hari para nelayan meminjam uang kepada tengkulak dengan bunga sesuai dengan perjanjian yang sudah disepakati, biasanya para nelayan membayar hutangnya pada saat musim ikan tiba. Dari fenomena diatas nampak jelas bahwa kemiskinan struktural dalam kehidupan nelayan dalam kawasan ini sangat sulit untuk dihindari. Kemiskinan struktural adalah kemiskinan yang di derita suatu golongan masyarakat, karena struktur sosial masyarakat itu tidak dapat ikut menggunakan sumber-sumber pendapatan yang sebenarnya tersedia bagi mereka.

\section{Masyarakat Pesisir}

Masyarakat pesisir adalah sekelompok masyarakat yang tinggal di wilayah pesisir yang hidup bersama dan memenuhi kebutuhan hidupnya dari sumber daya di wilayah pesisir. Demikian pula jenis mata pencaharian yang memanfaatkan sumber daya alam atau jasa-jasa lingkungan yang ada di wilayah pesisir seperti nelayan, mereka belum memiliki pilihan mata pencaharian, memiliki tingkat pendidikan yang rendah, tidak mengetahuidan menyadari kelestarian sumber daya alam dan lingkungan (Lewaherilla, 2002).

\section{METODE}

\section{A. Pendekatan dan Jenis Penelitian}

Metode Penelitian merupakan ilmu yang mempelajari atau alat untuk penelitian. Yaitu penelitian ini penulis menggunakan pendekatan kualitatif, yaitu penelitian yang bermaksud unuk memahami fenomena tentang apa yang di alami subjek penelitian misalnya perilaku, persepsi, motivasi, dan tindakan lain-lain (Lexy. J. Moleong, 2007). Jenis penelitian ini termasuk dalam jenis penelitian deskriptif, yaitu penelitian yang hanya menggambarkan, meringkas berbagai kondisi, situasi atau berbagai situasi.

\section{B. Lokasi Penelitian}

Penelitian ini memilih lokasi penelitian untuk menjadi objek dan subjek yang akan di teliti. Oleh sebab itu, yang menjadi subjek dalam penelitian ini yaitu Isteri Nelayan

$\begin{array}{lcc}\text { Dukuh } & \text { Senturi } & \text { Kelurahan } \\ \text { Karangasem } & \text { Utara } & \text { Kabupaten } \\ \text { Batang. } & & \end{array}$

\section{Fokus Penelitian}

Dalam penelitian ini yang menjadi fokus penelitian yaitu pengembangan sumber daya manusia pada masyarakat pesisir pantai, bahwa pengembangan sumber daya manusia adalah peningkatan pendidikan dan pelatihan atau usaha menambah pengetahuan dan keterampilan sebagai proses yang tanpa akhir. 


\section{D.Informan}

Yang dimaksud dengan informan dalam penelitian ini adalah orang-orang atau masyarakat yang berada di lokasi penelitian dan informan dalam penelitian Desa yang tinggi sumber daya manusianya, desa yang sedang sumber daya manusianya, dan desa yang rendah sumber daya manusianya.

\section{E.Sumber Data}

Penelitian deskripsi kualitatif ini menggunakan dua jenis data yaitu:
a. Data Primer
b. Data Sekunder

\section{F. Teknik Pengumpulan Data}
a. Obsevarsi
b. Wawancara
c. Dokumentasi

G. Teknik Analisa Data
a. Pengumpulan Data
b. Reduksi Data
c. Penyajian Data
d. VerifikasiData/Penarikan
Kesimpulan

\section{HASIL DAN PEMBAHASAN}

\section{A.Gambaran Umum Lokasi Penelitian}

Istri nelayan dukuh senturi kelurahan karangasem utara kabupaten batang terdiri 4 kelompok nelayan yaitu Berkah Makmur, Nelayan Karya, Nelayan Maju dan Gotong royong, dengan 64 peserta.

\section{B.Pembahasan}

Masyarakat pesisir merupakan masyarakat yang hidup di daerah pantai dan memiliki berbagai potensi sumber daya perikanan dan kelautan masyarakat pesisir juga di kenal dengan sebagai masyarakat nelayan karena kehidupan sehari-harinya sering melaut dan bekerja sebagai nelayan namun yang menjadi kendala saat ini yaitu masih kurangnya sumber daya manusia yang ada di masyarakat pesisir isteri Nelayan hanya menunggu dari hasil tangkap suami, Sesuai dengan indikator pengembangan sumber daya manusia yang dikemukakan Bahwa Pengembangan sumber daya manusia dalam arti luas adalah seluruh proses pembinaan untuk meningkatkan kualitas serta taraf hidup manusia dari suatu negara, sedangkan dalam arti sempit pengembangan sumber daya manusia adalah peningkatan pendidikan dan pelatihan merintis usaha menambah pengetahuan dan keterampilan sebagai proses yang tanpa akhir, terutama pengembangan diri sendiri di lingkungan istri nelayan.

a. Peningkatan Pendidikan dan Pelatihan Pendidikan dan pelatihan sangatlah penting dalam meningkatkan sumber daya manusia. Pendidikan sangat penting dalam mengembangkan sumber daya manusia terutama istri Nelayan. Peningkatan ketrampilan untuk berwirausaha yang secara kontinyu dari sebuah ide kemudian diberikan pelatihan dan didampingi untuk pemasaran sampai masyarakat bisa mandiri berwirausaha, pemasaran secara on line atau secara langsung lewat program-program pemerintah atau lingkungan pendidikan Tinggi, Pengetahuan ketrampilan merupakan instrumen yang penting bagi setiap orang untuk meningkatkan daya saing antar Negara. Pendidikan secara langsung atau Praktek sangatlah penting bagi setiap individu, dengan pendidikan dapat membantu mengembangkan potensi yang ada dalam diri sendiri disetiap individu dengan pendidikan kita mendapatkan kemampuan daya fikir yang positif. Dalam setiap masyarakat pasti mempunyai masalah dalam pendidikan seperti yang ada pada masyarakat pesisir Dukuh Seturi Kelurahan Karangasem Utara Kabupaten Batang karena masih rendahnya tingkat ketrampilan tingkat pendidikan pada masyarakat pesisir untuk itu masyarakat belum dapat mengoptimalkan pengelolaan 
potensi perikanan atau ketrampilan di bidang lain, yang mereka miliki hal inilah yang menambah rendahnya sumber daya manusia pada masyarakat pesisir pantai khususnya nelayan.

b. Peningkatan Pengetahuan dan

Keterampilan Pengetahuan dan keterampilan dalam pengembangan sumber daya manusia merupakan usaha yang harus dilakukan untuk membentuk Karakter manusia yang berkualitas dengan memiliki ilmu pengetahuan dan keterampilan, masyarakat pesisir pantai khususnya Dukuh Senturi Kelurahan Karangasem Utara Kabupaten Batang masih terbilang kurangnya memiliki pengetahuan dan keterampilan selain pengolahan hasil laut, misal mengelola potensi perikanan secara Higienis dan Modern pembuatan aroma terapi, pengolahan limbah kulit kerang,dll. Penguasaan pemasaran dan teknologi. Keterampilan yang dimiliki masyarakat pesisir khususnya istri nelayan diperoleh secara turun-temurun, sehingga kurang ada minat dan keinginan untuk dapat meningkatkan keterampilannya. Hal ini sangat diperlukan untuk meningkatkan pendapatan istri nelayan dan tidak bergantung pada hasil laut dan tidak ada peningkatan dalam kehidupan ekonomi. Oleh sebab itu, masyarakat belum bisa melihat keuntungan atau dampak dari peningkatan sumber daya manusia.

\section{KESIMPULAN DAN SARAN}

\section{A. Kesimpulan}

Berdasarkan hasil kajian dalam rangkuman wawancara dan pembahasan sebagaimana yang telah dikemukakan pada bagian sebelumnya, maka dapat disimpulkan bahwa:
1. Dilihat dari indikator peningkatan pendidikan dan pelatihan, pendidikan masyarakat pesisir masih sangat rendah untuk itu rendahnnya pemahaman masyarakat tentang pengolahan hasil tangkapan suami secara modern dan pola pikir untuk berwirausaha dalam bidang lain masih kurang, salah satu sebabnya adalah pelatihan yang diperoleh selama ini hanya sebatas syarat pelatihan tetapi tidak didampingi secara kontinyu sampai mereka menciptakan produk sesuai arahan atau produk sesuai dengan hobi, ide kreatif dari peserta dan kemudian memasarkan dan bisa mandiri sebagai indikator masyarakat pesisir lainnya.

2. Dilihat dari indikator peningkatan pengetahuan dan keterampilan masyarakat pesisir masih rendahnya sumber daya manusia pengetahuan dan keterampilan masyarakat terutama terhadap teknologi pemasaran setelah produk dari pelatiahan itu didapatkan.

\section{B. Saran}

Mengacu pada hasil temuan dalam penelitian ini maka dapat diberikan beberapa saran yang dapat dikemukakan agar dapat meningkatkan pengambangan sumber daya manusia pada masyarakat pesisir :

1. Hendaknya masyarakat pesisir mendapatkan peningkatan ketrampilan yang memadai khususnya isteri para nelayan, masih kurangnya pemahaman mengenai ketrampilan untuk berwirausaha selain hasil dari tangkapan laut.

2. Pendampingan yang sangat mereka butuhkan sesuai dengan keberadaaan teknologi saat ini.

\section{DAFTAR PUSTAKA}

Adi, Isbandi R. 2012. Inetvensi Komunitas dan Pengembangan Masyarakat Sebagai Upaya Pemberdayaan Masyarakat. Jakarta: penerbit.

Huda, Miftahul. 2009. Pekerjaan Sosial dan Kesejahteraan Sosial: Sebuah Pengantar. Yogyakarta: Pustaka Pelajar. 
Irawan, Prasetya. 2006. Penelitian Kualitatif \& Kuantitatif Untuk Ilmu-IlmuSosial. Jakarta : DIA FISIP UI.

Kusnadi. 2001. Pengamba' Kaum Perempuan Fenomenal. Bandung. Humaniora Utama Press.

Kuncoro, Mudrajad. 2006. Ekonomika Pembangunan: Teori, Masalah dan Kebijakan, Edisi Ke- empat UPP STIM YKPN 2006.

Kasmir, 2016 Manajeman sumber daya manusia. Depok. PT. Rajagrafindo Persada

Suryana 2003. pedoman praktis,kita dan proses menuju sukses

Satria, A. 2002. Pengantar Sosiologi Masyarakat Pesisir. Jakarta: Cidesindo.

Soebagio Atmodiwirio (2002) manajemen penedidikan Indonesia

Kamus Besar Bahasa Indonesia 2002 